\title{
Z PROBLEMATYKI UTRATY I ODZYSKANIA UPRAWNIEŃ ZAKŁADOWEJ ORGANIZACJI ZWIAZZKOWEJ
}

\author{
Abstract \\ On the loss and recovery of the rights of a trade union organization
}

The provisions of the Trade Union Act of 23 May 1991 concerning the loss and regaining the rights of a company trade union organization generate numerous interpretative doubts. The author analyses issues concerning the trade union organization's failure to comply with the obligation to provide the employer with information on the number of its members, the trade union organization's failure to timely submit an application to the labor court with jurisdiction over the employer's registered office to establish the number of its members as at the last day of the six-month period, and the organization's restoration of its rights as a result of the submission of an application to establish the number of its members. The author also draws up de lege ferenda postulates concerning the clarification of specific regulations, which should result in avoiding paralysis of the legitimate exercise of trade union rights and privileges by a trade union organization.

Słowa kluczowe: zakładowa organizacja związkowa, uprawnienia zakładowej organizacji związkowej, reprezentatywność, liczebność, wniosek o ustalenie liczebności, utrata uprawnień zakładowej organizacji związkowej, związki zawodowe, weryfikacja liczebności zakładowej organizacji związkowej, odzyskanie uprawnień organizacji zakładowej

Keywords: company trade union organization, powers of company trade union organization, representativeness, numerical strength, request for determination of numerical strength, loss of powers of company trade union organization, trade unions, verification of numerical strength of company trade union organization, recovery of the rights of a trade union organization

ASJC: 3308, JEL: K31

\section{Uwagi wstępne}

Obowiązujące od dnia 1 stycznia 2019 roku przepisy ustawy z dnia 23 maja 1991 roku o związkach zawodowych (Dz.U.2019, poz. 263 tekst jedn. ze zm., dalej: „ustawa o związkach zawodowych”) dotyczące utraty i odzyskania uprawnień zakładowej organizacji związkowej, niestety, nie są na tyle precyzyjne, aby nie generować wątpliwości interpretacyjnych. 
Zarówno utrata, jak i odzyskanie uprawnień zakładowej organizacji związkowej stanowią bardzo istotne zagadnienia, gdyż - jak wiadomo - wywierają one bezpośredni wpływ na sferę uprawnień pracowniczych, jak również determinują ocenę zgodności z prawem czynności pracodawcy, które wymagają współdziałania z organizacją związkową.

Jednym z zamierzonych przez ustawodawcę celów nowelizacji ustawy o związkach zawodowych było usunięcie rozmaitych wątpliwości interpretacyjnych dzięki uregulowaniu skutków zaniechania przez organizację związkową wykonania obowiązków informacyjnych. Przeniesienie do ustawy utrwalonego już przez lata w orzecznictwie Sądu Najwyższego skutku w postaci utraty uprawnień zakładowej organizacji związkowej, która nie przedstawiła pracodawcy w terminie informacji o liczbie członków, miało doprowadzić - jak się wydaje - do uczynienia prawnej możliwości weryfikacji liczby członków organizacji sprawną i skuteczną.

Liczne problemy praktyczne, które pojawiają się podczas stosowania regulacji dotyczących utraty i odzyskania uprawnień organizacji, wskazują, iż zamierzony przez ustawodawcę skutek w postaci usunięcia stanu niepewności nie do końca został osiągnięty.

\section{Niewypełnienie $\mathbf{w}$ terminie obowiązku przedstawienia pracodawcy informacji o liczbie członków}

Zgodnie z art. $25^{1}$ ustawy o związkach zawodowych organizacji, która nie wypełniła $\mathrm{w}$ terminie obowiązku przedłożenia pracodawcy informacji o liczbie członków (to jest informacji przekazywanej co sześć miesięcy, według stanu na dzień 30 czerwca i 31 grudnia, oraz informacji przekazywanej przez nowo powstałą organizację związkową $\mathrm{w}$ terminie dwóch miesięcy od dnia jej utworzenia), nie przysługują uprawnienia zakładowej organizacji związkowej do czasu wykonania tego obowiązku.

$\mathrm{Z}$ art. $25^{1}$ ust. 3 expresis verbis wynika, iż dwumiesięczny okres na przedstawienie informacji przez nowo utworzoną organizację liczy się od daty jej utworzenia, a zatem od dnia podjęcia uchwały założycielskiej.W doktrynie prawa pracy zwrócono już uwagę na wadliwość tej regulacji, gdyż w chwili przekazania informacji organizacja związkowa może nie być jeszcze zarejestrowana. W okresie tym nie posiada jeszcze prawa do działania, a tym samym nie przysługują jej żadne uprawnienia (Baran 2019, s. 9). Wydaje się zatem uprawniona teza, zgodnie z którą okres dwumiesięczny powinien być wystarczający na dopełnienie formalności rejestracyjnych, po których ukończeniu stosowna informacja o liczbie członków powinna być przedstawiona pracodawcy.

Podczas nowelizacji przepisów ustawy o związkach zawodowych nie została wskazana forma, w jakiej organizacja ma przedstawić pracodawcy informację o liczbie członków. Dodany w ust. 4 art. $25^{1}$ ustawy o związkach zawodowych obowiązek pracodawcy udostępnienia tej informacji „do wglądu” innej działającej u niego organizacji na jej pisemny wniosek wskazuje na to, iż nie może być ona przedstawiona w formie ustnej.

Co więcej, z uwagi na to, iż przedstawienie pracodawcy informacji o liczbie członków rozpoczyna bieg trzydziestodniowego terminu na złożenie zastrzeżenia, o którym mowa 
w art. $25^{1}$ ust. 7 ustawy o związkach zawodowych, informacja przekazywana pracodawcy powinna być sporządzona zgodnie z zasadami reprezentacji organizacji związkowej, określonej w statutach poszczególnych związków zawodowych, i opatrzona podpisami osób uprawnionych do składania oświadczeń w imieniu organizacji zakładowej. Należy stwierdzić, iż w zasadzie tylko forma pisemna gwarantuje pewność prawa co do tego, czy informacja pochodzi od osób uprawnionych do działania w imieniu organizacji, z uwagi na zamieszczenie podpisów pod treścią oświadczenia, a także odnośnie tego, kiedy (ze wskazaniem daty) oświadczenie to zostało złożone. Nie można bowiem nie zauważyć, iż wskazana nowa regulacja wprowadzająca obowiązek pracodawcy okazania na pisemny wniosek innej działającej u niego organizacji związkowej informacji z podaną liczbą członków przemawia za przedstawionym kierunkiem wykładni. Dla tej organizacji data przekazania informacji pracodawcy jest wiążąca w zakresie rozpoczęcia również dla niej biegu trzydziestodniowego terminu na zgłoszenie pisemnych zastrzeżeń co do liczebności danej organizacji związkowej. Nie do zaakceptowania są zatem jakiekolwiek wątpliwości interpretacyjne odnośnie do rozpoczęcia biegu tego terminu. $Z$ tego względu nie wydaje się prawnie dopuszczalne uznanie za prawidłowe przekazanie takiej informacji w innej niż pisemna formie.

Warte podkreślenia jest to, iż pracodawca jest zobligowany do udostępniona rzeczonej informacji jedynie do wglądu, a zatem nie ma podstaw prawnych do żądania przekazania jej kopii pocztą lub drogą elektroniczną. Wgląd do tej informacji w sposób wystarczający pozwala na pozyskanie przez organizację związkową niezbędnych informacji, czyli daty przekazania pracodawcy informacji o liczbie członków, od której również dla organizacji związkowej zainteresowanej zakwestionowaniem liczebności rozpoczyna się bieg trzydziestodniowego terminu, jak również samej treści informacji, która może być przedmiotem weryfikacji.

\section{Niewypełnienie $\mathbf{w}$ terminie obowiązku wystąpienia do sądu pracy - właściwego ze względu na siedzibę pracodawcy - z wnioskiem o ustalenie liczby członków na ostatni dzień półrocza}

W uzasadnieniu projektu ustawy zmieniającej ustawę o związkach zawodowych wskazano, iż przez wprowadzenie zapisu dotyczącego utraty uprawnień zakładowej organizacji związkowej zmierzano do tego, aby jednoznacznie przesądzić o konsekwencjach prawnych zaniechania przez organizację związkową wykonania przewidzianych w ustawie obowiązków informacyjnych. Co więcej, jak czytamy w dalszej części uzasadnienia, dostrzeżona została potrzeba wprowadzenia trybu kontroli spełniania kryteriów liczebności przez organizację związkową. Liczebność organizacji związkowej decyduje bowiem o możliwości korzystania przez organizację związkową z wielu uprawnień zagwarantowanych przepisami prawa. Liczebność związku przesądza także o zakresie jego uprawnień, stąd też jest ona istotną kwestią nie tylko dla jej członków, lecz 
również dla pracodawcy. Uprawnienia organizacji związkowej są bowiem skorelowane z obowiązkami pracodawcy, niejednokrotnie związanymi z obciążeniem finansowym.

Do przepisów ustawy dodane zostało zatem rozwiązanie uprawniające zarówno pracodawcę, jak i każdą działającą u niego organizację związkową do zgłoszenia pisemnego zastrzeżenia co do liczebności danej zakładowej organizacji związkowej $\mathrm{w}$ terminie trzydziestu dni od dnia przedstawienia przez tę organizację informacji o liczbie członków (ust. 7 art. $25^{1}$ ustawy o związkach zawodowych).

Zakładowa organizacja związkowa, wobec której takie zastrzeżenie zostało zgłoszone, ma obowiązek wystąpić do sądu rejonowego - sądu pracy właściwego ze względu na siedzibę pracodawcy - z wnioskiem o ustalenie liczby jej członków na ostatni dzień danego półrocza. W przypadku zaniechania tego obowiązku w terminie trzydziestu dni od dnia zgłoszenia zastrzeżenia organizacji tej nie przysługują uprawnienia zakładowej organizacji związkowej do czasu wykonania tego obowiązku.

Zakładowa organizacja związkowa może również z własnej inicjatywy wystąpić z wnioskiem o ustalenie liczby członków. Ustawa o związkach zawodowych w art. $25^{1}$ ust. 8 statuuje zatem dwa odrębne tryby sądowej weryfikacji liczby członków. Z uwagi na sankcję w postaci utraty uprawnień wniosek organizacji, o którym mowa w zdaniu pierwszym, można określić jako względnie obligatoryjny, natomiast drugi z trybów polegający na wystąpieniu z własnej inicjatywy z wnioskiem o ustalenie liczebności - jako fakultatywny.

Na pozór mogłoby się wydawać, iż mechanizm utraty i odzyskania uprawnień zakładowej organizacji związkowej w sytuacjach uregulowanych w art. $25^{1}$ ust. 6 i ust. 9 ustawy o związkach zawodowych jest identyczny, co więcej, nie powinien wywoływać wątpliwości interpretacyjnych, gdyż podczas prac nad nowelizacją przepisów brane były pod uwagę dotychczasowe liczne problemy praktyczne i interpretacyjne.

Wspólnym elementem obydwu tych sytuacji jest to, iż utrata uprawnień, jak również ich odzyskanie przez organizację związkową następuje ex lege. Poprawne złożenie informacji o liczbie członków, jak również wystąpienie we właściwym trybie z wnioskiem do sądu rejonowego - sądu pracy właściwego z uwagi na siedzibę pracodawcy - restytuuje uprawnienia organizacji ex nunc.

Analizując zagadnienie restytucji uprawnień zakładowej organizacji związkowej z perspektywy wpływu na zakres obowiązków pracodawcy, które są pochodną uprawnień zakładowej organizacji związkowej, należy stwierdzić, iż tylko na pozór nie ma różnicy między tymi dwiema sytuacjami, w których następuje restytucja uprawnień zakładowej organizacji związkowej, gdyż utrata uprawnień pozostaje w mocy „ do czasu wykonania naruszonego przez organizację obowiązku”. Z praktycznego punktu widzenia zachodzą między nimi różnice bardzo istotne w skutkach.

W przypadku gdy organizacja związkowa traci uprawnienia na skutek niewykonania obowiązku informacyjnego wynikającego $\mathrm{z}$ art. $25^{1}$ ust. 2 lub ust. 3 ustawy o związkach zawodowych, aby nastąpiła restytucja tychże uprawnień organizacji, adresatem tej spóźnionej informacji musi być pracodawca. Oznacza to, iż w analizowanej sytuacji nie zachodzi po stronie pracodawcy wątpliwość o charakterze temporalnym co do tego, od kiedy na nowo powinien współdziałać z organizacją związkową, gdyż znana jest mu 
zarówno data utraty uprawnień (upływ terminów ustawowych), jak również moment, od którego organizacja odzyskuje uprawnienia. Co prawda, w doktrynie prawa pracy zwrócono uwagę na przynajmniej teoretyczną możliwość innej wykładni odnośnie do tego, od kiedy restytuują się uprawnienia, a mianowicie, iż nie będzie to następowało bezpośrednio po złożeniu pracodawcy informacji, lecz dopiero po upływie następnego ustawowo określonego okresu. Ta opcja interpretacyjna została jednak zasadnie odrzucona zarówno z uwagi na tekstualne brzmienie przepisów, jak również z uwagi na wymiar aksjologiczny (Baran 2019, s. 10).

Zupełnie inaczej z perspektywy obowiązków pracodawcy wygląda sytuacja, w której utrata uprawnień zakładowej organizacji związkowej następuje wskutek zaniechania wykonania przez tę organizację obowiązku wystąpienia do sądu rejonowego - sądu pracy właściwego ze względu na siedzibę pracodawcy - z wnioskiem o ustalenie liczby członków, wskutek zgłoszenia wobec niej - przez pracodawcę lub działającą u niego inną organizację związkową - pisemnego zastrzeżenia co do jej liczebności.

Z przepisów ustawy o związkach zawodowych wynika, iż zarówno zgłoszenie pisemnych zastrzeżeń, jak również wystąpienie do sądu z wnioskiem o ustalenie liczby członków są ograniczone terminem. Pisemne zastrzeżenie może zostać zgłoszone przez pracodawcę lub działającą u niego organizację związkową w terminie trzydziestu dni od dnia przedstawienia pracodawcy informacji o liczbie członków. Zgłoszenie zastrzeżenia rozpoczyna bieg trzydziestodniowego terminu, w trakcie którego organizacja, wobec której zastrzeżenie zostało zgłoszone, zachowuje co prawda swoje uprawnienia w zakresie wynikającym z liczby członków podanej w informacji, ale utraci je z chwilą bezskutecznego upływu tego terminu.

W związku z tym może powstać wątpliwość, skąd pracodawca miałby pozyskać wiedzę o bezskutecznym upływie terminu wystąpienia do sądu o ustalenie liczby członków, a w konsekwencji o utracie uprawnień zakładowej organizacji związkowej, gdy to nie on, a działająca u niego organizacja związkowa zgłasza zastrzeżenie co do liczebności.

Wnikliwa analiza całokształtu zmian w przepisach prawa pracy, jakiej dokonano ustawą z dnia 5 lipca 2018 roku o zmianie ustawy o związkach zawodowych oraz niektórych innych ustaw (Dz.U. 2018, poz. 1608 ze zm.) dostarcza dodatkowych argumentów odnośnie do właściwego kierunku wykładni analizowanej regulacji. W obowiązującym stanie prawnym w celu stwierdzenia reprezentatywności organizacji związkowych przepisy art. $25^{1}$ ust. 2-12 ustawy o związkach zawodowych znajdują bowiem odpowiednie zastosowanie, a zatem przewidziany w art. $25^{1}$ ust. 7-9 tryb służący weryfikacji liczebności zakładowej organizacji związkowej zastąpił bardzo zbliżoną do niego regulację z uchylonego art. 241 ${ }^{25 a}$ ustawy z dnia 26 czerwca 1974 roku - Kodeks pracy (Dz.U. 2020, poz. 1320 tekst jedn. ze zm.). W $\$ 4$ tegoż artykułu przewidziane było prawo do zgłoszenia przez zakładową organizację związkową przed zawarciem układu zakładowego uczestnikom prowadzącym rokowania w sprawie zawarcia tego układu pisemnego zastrzeżenia co do spełniania przez inną zakładową organizację związkową kryteriów reprezentatywności. Prawo do zgłoszenia zastrzeżenia z mocy tej normy przysługiwało również pracodawcy. Należy zaakcentować, iż w przepisie tym zostało wyraźnie zapisane, iż zastrzeżenie 
odnośnie do reprezentatywności składane było „uczestnikom prowadzącym rokowania”. Tak samo jak w obecnie obowiązującej regulacji zakładowa organizacja związkowa, wobec której zostało zgłoszone zastrzeżenie, była obowiązana do wystąpienia do sądu rejonowego - sądu pracy właściwego dla siedziby pracodawcy z wnioskiem o stwierdzenie jej reprezentatywności.

Mankamentem poprzednio obowiązującej regulacji było jednak to, że ustawodawca nie przewidział w niej ani terminu, przed upływem którego organizacja związkowa, której reprezentatywność została zakwestionowana, ma się poddać sądowej weryfikacji, ani sankcji za zaniechanie $\mathrm{w}$ tym przedmiocie. W doktrynie prawa pracy jednak już wówczas przyjmowano, iż zgłoszenie we właściwym trybie zastrzeżeń w tym zakresie automatycznie powoduje utratę przymiotu reprezentatywności. Wykazanie, że jest inaczej, czyli że dana organizacja związkowa spełnia ustawowe kryteria reprezentatywności, musi zostać dowiedzione przed sądem w odpowiednim postepowaniu (Sanetra 2013).

Mając na uwadze, iż skutek w postaci utraty uprawnień zakładowej organizacji związkowej (podobnie jak ewentualnej utraty przymiotu reprezentatywności na skutek odpowiedniego stosowania tej regulacji) ma niebagatelny wpływ na zakres obowiązków pracodawcy, uzasadniona wydaje się interpretacja, zgodnie z którą ustawodawca w art. $25^{1}$ ust. 8 ustawy o związkach zawodowych nieprzypadkowo posługuje się określeniem „zakładowa organizacja związkowa, wobec której zostało zgłoszone zastrzeżenie”, a nie „której” zgłoszono takie zastrzeżenie. W związku z tym uważam, że działająca u pracodawcy organizacja związkowa, która zgłasza zastrzeżenie co do liczebności danej organizacji związkowej powinna dokonać tego w taki sposób, by umożliwić pracodawcy ustalenie terminu, z upływem którego nastąpi urata uprawnień zakładowej organizacji związkowej.

\section{Odzyskanie uprawnień wskutek wystąpienia z wnioskiem o ustalenie liczby członków}

Zgodnie z art. $25^{1}$ ust. 9 ustawy o związkach zawodowych organizacji związkowej, która w terminie trzydziestu dni od dnia zgłoszenia zastrzeżenia nie wystąpiła do sądu, do czasu wykonania tego obowiązku nie przysługują uprawnienia zakładowej organizacji związkowej. Z racji tego, iż wystąpienie $\mathrm{z}$ wnioskiem $\mathrm{z}$ własnej inicjatywy jest fakultatywne, nie może oznaczać, iż z datą jego złożenia organizacja odzyskuje utracone uprawnienia. Co więcej, ustawa o związkach zawodowych jednoznacznie przesądza, iż sądem właściwym do przeprowadzenia postępowania zainicjowanego wnioskiem złożonym wskutek zastrzeżenia (art. $25^{1}$ ust. 8 zd. 1) jest sąd rejonowy - sąd pracy właściwy ze względu na siedzibę pracodawcy niezależnie od tego, czy zastrzeżenie to pochodziło od pracodawcy, czy też od innej działającej u niego organizacji związkowej. Tego rodzaju spraw nie może zatem rozpatrywać sąd, którego właściwość ustalono według reguł ogólnych. Nie będzie zatem właściwym miejscowo sąd ustalony według siedziby wnioskodawcy. Przepis ustawy o związkach zawodowych wprowadza w ten sposób 
modyfikację ogólnych reguł postepowania cywilnego obowiązujących przy ustalaniu właściwości miejscowej sądu w postępowaniu nieprocesowym. Co więcej, ustawodawca jednoznacznie przesądził, iż w postępowaniu zainicjowanym wnioskiem złożonym wskutek zastrzeżenia sąd zawsze dokonuje ustalenia liczby członków na ostatni dzień danego półrocza. A contrario wydaje się, iż w przypadku wniosku o ustalenie liczby członków składanego z własnej inicjatywy sąd może dokonać ustalenia tej liczby na dzień wskazany we wniosku. Nie wyklucza to oczywiście, iż może to być ostatni dzień danego półrocza, ale w tym przypadku nie jest to obligatoryjne.

Literalna wykładnia przepisu prowadzi do wniosku, iż skoro organizacja związkowa nie korzysta z uprawnień zakładowej organizacji związkowej do czasu wykonania tego obowiązku, to z dniem złożenia spóźnionego wniosku o ustalenie liczebności z mocy prawa następuje restytucja wszystkich uprawnień, które przepisy prawa pracy przyznają organizacji zakładowej.

W związku z tym pojawia się wymagające rozważenia zagadnienie, czy wystąpienie $\mathrm{z}$ wnioskiem do sądu, z którym ex lege powiązane jest odzyskanie uprawnień związkowych, z tą samą datą wywołuje skutek wobec pracodawcy. De lege lata żaden przepis prawa nie nakłada jednak na organizację związkową obowiązku przekazania pracodawcy informacji o wystąpieniu z takim wnioskiem. Również nie ma regulacji wskazującej na powinności przekazania informacji o tym, że z takowym wnioskiem organizacja wystąpiła $w$ ustawowym terminie, co również miałoby niebagatelne znaczenie chociażby dla tych sytuacji, w których - przykładowo - strony są w trakcie sporu zbiorowego czy też prac nad wprowadzeniem zmian do wewnątrzzakładowych źródeł prawa pracy. Wydaje się, iż w interesie organizacji powinno być wykazanie, iż zachowała swoje uprawnienia i może nieprzerwanie uczestniczyć $\mathrm{w}$ dialogu z pracodawcą, a także że nie zostaje przerwana ochrona szczególna członków jej zarządu czy też członków upoważnionych do reprezentowania tej organizacji wobec pracodawcy.

Jak już zostało zasygnalizowane, w odróżnieniu od regulacji z art. $25^{1}$ ust. 6 ustawy o związkach zawodowych w analizowanym przypadku to sąd rejonowy - sąd pracy jest adresatem czynności organizacji związkowej, wskutek których miałaby z mocy prawa nastąpić restytucja uprawnień organizacji związkowej. Brak wiedzy po stronie pracodawcy mógłby skutkować wadliwością czynności podejmowanych z pominięciem organizacji związkowej, którą postrzega jako pozbawioną uprawnień zakładowej organizacji związkowej.

Pomimo zmiany stanu prawnego nie straciło jednak na aktualności orzecznictwo Sądu Najwyższego, w którym przedmiotem analizy jurydycznej było znaczenie - dla zakresu obowiązków pracodawcy - przedłożenia w późniejszym terminie informacji o tym, że dana organizacja związkowa utraciła swoje uprawnienia. W istocie bowiem wprowadzając analizowaną regulację, ustawodawca usankcjonował utrwalony od dawna kierunek wykładni Sądu Najwyższego.

Posiłkując się zatem orzecznictwem Sądu Najwyższego, z okresu kiedy przepisy ustawy o związkach zawodowych nie regulowały kwestii utraty i odzyskania uprawnień zakładowej organizacji związkowej, można podjąć się obrony twierdzenia, zgodnie 
z którym odzyskanie uprawnień organizacji związkowej może wywołać skutek wobec pracodawcy dopiero po tym, jak zostanie o tym przez organizację powiadomiony.

Sąd Najwyższy w powiększonym składzie, rozstrzygając wątpliwości interpretacyjne związane z poprzednim brzmieniem art. $25^{1}$ ustawy o związkach zawodowych (uchwała składu siedmiu sędziów Sądu Najwyższego z dnia 20 grudnia 2012 roku, III PZP 7/12, OSNP 2013, nr 9-10, poz. 101), stwierdził, że przepis tego artykułu należy odczytywać w całości. Norma zakodowana w jego jednostkach redakcyjnych jest jedna. Uprawnienia zakładowej organizacji związkowej przysługują organizacji zrzeszającej co najmniej dziesięciu członków. Organizacja musi tego dowieść w konkretny, ustawowo określony sposób, to jest przedstawić pracodawcy informację o łącznej liczbie członków tej organizacji. Taka interpretacja uwzględnia interes obu partnerów społecznych.

W uzasadnieniu powyższego rozstrzygnięcia zwrócono uwagę na jakże istotny z punktu widzenia rozpatrywanego zagadnienia aspekt, a mianowicie na konieczność wyważenia praw i interesów obu stron. Sąd Najwyższy stwierdził bowiem, że przy interpretacji przepisów ustawy o związkach zawodowych trzeba oczywiście brać pod uwagę zasady prawa i wolności związkowe, ale jednocześnie nie można abstrahować od praw drugiej strony, zobowiązanej do respektowania uprawnień organizacji zakładowej, to jest od sytuacji pracodawcy i konieczności chronienia także jego interesu, który trzeba widzieć w dążeniu do sprawnego funkcjonowania zakładu pracy. Nie będzie to możliwe w sytuacji braku pewności co do liczby partnerów społecznych, z którymi w konkretnych sprawach trzeba prowadzić dialog czy zawierać porozumienia (uchwała składu siedmiu sędziów Sądu Najwyższego z dnia 20 grudnia 2012 roku, III PZP 7/12, OSNP 2013, nr 9-10, poz. 101).

W podobnym duchu wypowiedział się Sąd Najwyższy w wyroku z dnia 6 października 2011 roku (III PK 17/11, OSNP 2012, nr 21-22, poz. 257), stwierdzając, iż zasadniczą funkcją nałożenia na zakładową organizację związkową obowiązku przekazania informacji jest ochrona pracodawcy przed negatywnymi dla niego konsekwencjami naruszenia uprawnień tej organizacji, spowodowanymi niewiedzą o spełnieniu przez organizację wymagań określonych $w$ art. $25^{1}$ ust. 1 .

W dalszych wywodach uzasadnienia Sąd Najwyższy odniósł się do kwestii ryzyka zachowania organizacji w sposób sprzeczny z ustawą. Co prawda, odniósł się on do obowiązku informacyjnego, który już wtedy wynikał wprost z przepisów ustawy, ale nie był w niej uregulowany skutek w postaci utraty i odzyskania uprawnień zakładowej organizacji związkowej. Kwestia, która jest obecnie przedmiotem prowadzonej analizy w zakresie celowościowym, jest bardzo zbliżona, pomimo że w ustawie nie został zapisany obowiązek przekazania pracodawcy informacji o złożeniu właściwego wniosku. Sąd Najwyższy zwrócił bowiem uwagę, iż ryzyko działania powinien ponosić ten, kto czerpie z niego korzyść. Beneficjentami uprawnień wynikających $\mathrm{z}$ art. $25^{1}$ ust. 1 ustawy o związkach zawodowych są, między innymi, działacze zakładowej organizacji związkowej korzystający z ochrony przewidzianej w art. 32 tej ustawy. Oni zatem powinni być obciążeni ryzykiem nieprzekazania przez organizację informacji z art. $25^{1}$ ust. 2, tym bardziej, że mają znaczny wpływ na właściwe wykonanie tego obowiązku przez 
organizację związkową. Brak możliwości korzystania z uprawnień przysługujących zakładowej organizacji związkowej - spełniającej warunki określone w art. $25^{1}$ ust. 1 ustawy o związkach zawodowych - będący skutkiem nieprzekazania pracodawcy informacji $\mathrm{z}$ art. $25^{1}$ ust. 2 nie jest sankcją nadmiernie dolegliwą czy nieproporcjonalną w stosunku do tego zaniedbania organizacji związkowej. Przekazanie tej informacji nie jest bowiem działaniem uciążliwym lub trudnym do spełnienia, wymaga ono dołożenia choćby minimalnej staranności ze strony organizacji związkowej, dbałości o własne interesy i interes osób objętych ochroną z art. 32 ustawy o związkach zawodowych.

W tym świetle w pełni uzasadnione wydaje się oczekiwanie, aby organizacja związkowa, która utraciła uprawnienia wskutek niewystąpienia w terminie do sądu rejonowego sądu pracy właściwego ze względu na siedzibę pracodawcy - dla skutecznego wobec pracodawcy odzyskania uprawnień związkowych - wykazała się dbałością nie tylko o własne interesy, ale przede wszystkim o interesy swoich członków, jak również całej załogi, której zbiorowe interesy reprezentuje. Niezwłoczne poinformowanie pracodawcy o wniesieniu stosownego wniosku, podobnie jak przekazanie informacji o liczbie członków, nie jest bowiem, jak zauważył Sąd Najwyższy, czynnością uciążliwą nieproporcjonalnie do wagi zagadnienia czy też skomplikowaną.

Za zasadnością stawianej w niniejszym opracowaniu tezy - zgodnie z którą wniesienie przez organizację związkową we właściwym trybie spóźnionego wniosku o ustalenie liczby członków, powodujące ex lege odzyskanie uprawnień zakładowej organizacji związkowej, będzie skuteczne dopiero po tym, jak pracodawca zostanie o tym poinformowany - przemawiają również wywody Sądu Najwyższego zawarte w uzasadnieniu wyroku z dnia 19 sierpnia 2015 roku (II PK 208/14, OSNP 2017, nr 7, poz. 82). Powołując się na stanowisko Krzysztofa Wojciecha Barana z komentarza do art. $25^{1}$ ustawy o związkach zawodowych, Sąd Najwyższy zgodził się z poglądem, iż utrata uprawnień na mocy tej normy może być w praktyce przejściowa. Jeśli bowiem nastąpi zwiększenie liczby członków ponad limit ilościowy określony w ust. 1, następuje ex lege restytucja uprawnień. Ma to miejsce w dniu poinformowania o tym fakcie pracodawcy.

Zgodnie z tą wykładnią dla korzystania z uprawnień związkowych decydujące jest przekazanie pracodawcy określonej informacji, niezależnie od tego, od kiedy zaistniał stan faktyczny takie uprawnienia przywracający. Sąd Najwyższy w wyroku z dnia 21 marca 2019 roku (II PK 313/17, OSNP 2019, nr 12, poz. 142) stwierdził, iż biorąc pod uwage specyfikę międzyzakładowej organizacji związkowej, pracodawca nie ma żadnej wiedzy o objęciu go działaniem tej organizacji, dopóki związek zawodowy bądź jego członkowie takiej informacji mu nie przekażą.

Ochrona działacza związkowego, wynikająca z art. 32 ust. 1 ustawy o związkach zawodowych, przerwana po utracie wymaganej liczby członków zakładowej organizacji związkowej, ulega reaktywacji i przedłużeniu wymiaru temporalnego o połowę dotychczasowej ochrony, w przypadku połączenia zakładowej organizacji związkowej z organizacją międzyzakładową, jeśli ta międzyzakładowa organizacja związkowa przejęła wszystkie prawa i obowiązki zakładowej organizacji związkowej. W konkluzji Sąd Najwyższy stwierdził, że pracodawca ma obowiązek uzyskania zgody międzyzakładowej 
organizacji związkowej na rozwiązanie z działaczem związkowym umowy o pracę, jeśli międzyzakładowa organizacja związkowa poinformowała pracodawcę o dokonanej inkorporacji (wyrok Sądu Najwyższego z dnia 21 marca 2019 roku, II PK 313/17, OSNP 2019, nr 12, poz. 142).

\section{5. (Nie)odzyskanie uprawnień utraconych wskutek naruszenia obowiązku, o którym mowa w art. $25^{1}$ ust. 8 ustawy o związkach zawodowych, z dniem złożenia kolejnej informacji półrocznej}

Wbrew założeniu ustawodawcy praktyka pokazuje, iż z uwagi na złożoność postępowań zmierzających do ustalenia właściwej liczby członków organizacji związkowej niejednokrotnie dochodzi do znacznego przekroczenia sześćdziesięciodniowego terminu na wydanie orzeczenia od dnia złożenia wniosku. Może się zatem okazać, iż sąd nie zdąży wydać przedmiotowego rozstrzygnięcia przed nadejściem kolejnego terminu sprawozdawczego, zwłaszcza w przypadku wniosków złożonych po upływie przewidzianego w ustawie trzydziestodniowego terminu od dnia zgłoszenia zastrzeżenia. W związku z tym z uwagi na nieustalenie liczby członków, a zatem niemożność ustalenia, iż uprzednio zgłoszone zastrzeżenie było bezpodstawne, możliwe będzie ponowne zgłoszenie zastrzeżenia co do liczebności tej samej organizacji związkowej. Co więcej, wydaje się oczywiste, iż w takiej sytuacji organizacja ta powinna ponowić wniosek o ustalenie liczby jej członków na ostatni dzień kolejnego półrocza.

Wobec tego można sobie wyobrazić również taką sytuację, że organizacja, która znacząco uchybiła terminowi do wystąpienia do sądu z wnioskiem, który powinien być złożony wskutek zastrzeżenia (art. $25^{1}$ ust. 8 zd. 1), może uznać, iż z uwagi na zbliżający się kolejny termin do przedstawienia pracodawcy informacji o liczbie członków wniosek taki jest już bezcelowy, gdyż z chwilą wykonania kolejnego obowiązku informacyjnego i tak odzyska utracone uprawnienia, powołując się na treść art. $25^{1}$ ust. 6 ustawy o związkach zawodowych. W mojej ocenie taka interpretacja jest całkowicie nieuzasadniona z co najmniej dwóch powodów. Po pierwsze są dwie zupełnie odmienne sytuacje powodujące utratę uprawnień zakładowej organizacji związkowej, z którymi skorelowane są odmienne tryby ich restytucji. Innymi słowy, uprawnień utraconych przez organizację, wobec której zostało zgłoszone zastrzeżenie wskutek niewystąpienia do sądu pracy we właściwym terminie z wnioskiem o ustalenie liczby członków, nie może przywrócić wykonanie innego obowiązku, w tym przypadku przedstawienie pracodawcy informacji o liczbie członków.

Organizacja związkowa, która w pełni świadomie przyjęła na siebie ryzyko przejściowej utraty uprawnień i nie poddała się sądowej weryfikacji liczebności swoich członków, miałaby je odzyskać wskutek przedłożenia kolejnego sprawozdania? Wyrażam pogląd, iż konstatacja taka nie jest dopuszczalna, a odmienna wykładnia godziłaby bezpośrednio w zakaz wykładni per non est, ponieważ w znacznej mierze pozbawiałaby znaczenia regulacji art. $25^{1}$ z ust 9 ustawy o związkach zawodowych. W konsekwencji oznaczałoby to powrót do stanu sprzed nowelizacji, która zgodnie z zamierzeniem ustawodawcy miała 
skutecznie ukrócić występowanie stanu niepewności odnośnie do rzeczywistej liczebności organizacji związkowych właśnie przez swoisty mechanizm wymuszonej kontroli sądowej.

\section{Podsumowanie}

Jak wynika z podniesionych w niniejszym opracowaniu kwestii, których wykładnia może sprawiać istotne problemy wszystkim adresatom wprowadzonych do ustawy regulacji prawnych, zasadne jest rozważenie przez ustawodawcę doprecyzowania przynajmniej tych zagadnień, które niewłaściwie interpretowane mogą paraliżować zgodne z prawem korzystanie przez organizację związkową z jej ustawowych praw i przywilejów związkowych. Co więcej, stan niepewności interpretacyjnej może generować wiele problemów orzeczniczych również w indywidualnych sprawach z zakresu prawa pracy. Z perspektywy indywidualnych spraw pracowniczych, w których pracodawca podejmuje określone działania z pominięciem trybu konsultacji z organizacją związkową, niepewność momentu, w którym organizacja związkowa odzyskuje utracone uprawnienia, wydaje się na tyle ważną kwestią, że do czasu ewentualnej interwencji ustawodawcy można zasadnie oczekiwać, iż przy pierwszej nadarzającej się okazji Sąd Najwyższy wypowie się w tej sprawie.

\section{Bibliografia}

Baran K.W. (2019) Z problematyki liczebności zakładowej organizacji związkowej, „Monitor Prawa Pracy", nr 5.

Sanetra W. (2013) [w:] J. Iwulski, W. Sanetra, Kodeks pracy. Komentarz, wyd. 3, Warszawa.

\section{Orzecznictwo}

Uchwała składu siedmiu sędziów Sądu Najwyższego z dnia 20 grudnia 2012 roku, III PZP 7/12, OSNP 2013, nr 9-10, poz. 101.

Wyrok Sądu Najwyższego z dnia 6 października 2011 roku, III PK 17/11, OSNP 2012, nr 21-22, poz. 257.

Wyrok Sądu Najwyższego z dnia 19 sierpnia 2015 roku, II PK 208/14, OSNP 2017, nr 7, poz. 82.

Wyrok Sądu Najwyższego z dnia 21 marca 2019 roku, II PK 313/17, OSNP 2019, nr 12, poz. 142.

\section{Akty prawa krajowego}

Ustawa z dnia 26 czerwca 1974 roku - Kodeks pracy, Dz.U. 2020, poz. 1320 tekst jedn. ze zm. Ustawa z dnia 23 maja 1991 roku o związkach zawodowych, Dz.U. 2019, poz. 263 tekst jedn. ze $\mathrm{zm}$.

Ustawa z dnia 5 lipca 2018 roku o zmianie ustawy o związkach zawodowych oraz niektórych innych ustaw, Dz.U. 2018, poz. 1608 ze zm. 